\title{
影響係数法によるH 形鋼の圧延寸法制御法
}

\author{
有泉 孝*・平沢 猛志*・中内 一郎*2 - 森岡 清孝*2 ・脇本 信幸*3
}

A Method to Control Dimensions of H-Beams Using Influence Coefficients Method

Takashi Arizumi, Takeshi Hirasawa, Ichiro Nakauchi, Kiyotaka Morioka and Nobuyuki Wakimoto

Synopsis : H-beams are manufactured by multiple reverse rolling through universal mill and edger. In this process, complexity of relationship among rolling parameters makes it difficult to get H-beams with closed tolerance.

The objectives of this study are to clear the effect of each rolling parameter on dimensions and develop the method for controlling dimensions with accuracy. In this study, the influence coefficients method available for making effects of many parameters clear quantitatively was used to attain the objectives.

Firstly, fundamental equations are made up based on mathematical model of rolling and characteristics of mills such as mill spring.

Secondly, dimensional variation caused by change in rolling conditions was investigated by analysis using fundamental equations and the relation between dimensions and rolling parameters was clarified.

Thirdly, the rule for controlling dimensions was established by applying influence coefficients method to calculate the modified roll gaps for getting H-beams with higher accuracy.

Finally, the application of this method for practical operation verified its validity for rolling H-beams with closed tolerance. Especially, the universal mill with the function for moving upper horizontal roll in the axial direction results in the remarkable improvement for decreasing the deviation among wall thicknesses at four flange parts.

Key words : H-beams ; rolling ; universal mill ; edger ; dimensions controll ; influence coefficients method.

\section{1. 緒言}

形鋼製品のうち $50 \%$ 以上を占める $\mathrm{H}$ 形䤱は，通常ユニバ ーサルミルとエッジャを用いて压延されるが，ウェブ・フ ランジを有する断面形状の複雑さやユニバーサルミルにお ける水平ロール・竪ロールを同一平面とするミルの構造上 の点から板庄延に比べてウェブ・フランジ寸法のバラッキ が大きくなり易い。しかし最近のJIS規格の改定や外法一定 H形鋼製造の高精度化に見られるように需要家の要望に対 忍していくためにはこの寸法精度を今後さらに向上させる ことが重要な課題となっている。

それには，まず $\mathrm{H}$ 形鋼の圧延の基礎特性を把握すること が必要であり,縮尺 $1 / 7.5$ の鉛モデル圧延実験ならびに福山 第 1 大形工場での実機試験を行ってユニバーサル压延とエ ッジャ压延での変形挙動および压延負荷を調査し，フラン ジ幅広がり ${ }^{122)}$ ，庄延荷重 ${ }^{122}$ の数式モデルを作成した。また 一方，実機のユニバーサルミルおよびエッジャの設備面の 特性を調査解明し，ロール開度零点調整方法 ${ }^{3)}$ 確立した。

本報ではこれらをもとに，多数の圧延因子が相互に影響
し合う, H形鋼の寸法制御に有効な解決方法の一つと考え られる影響係数法4) 6) 導入し, 総合特性の解析を行うと共 に，制御則を確立し実機適用を図ったのでその結果を報告 する。

\section{2. 基本方程式}

H形鋼の圧延パス方法は一般的には, Fig. 1, Fig. 2 に示 すュニバーサルミルとエッジャのレバース圧延において

$\mathrm{U} 1$ (ユニバーサルミル 1 パス目) $\rightarrow \mathrm{E} 1$ (エッジャ 1 パス目) $\rightarrow \mathrm{U} 2 \rightarrow \mathrm{U} 3 \rightarrow \mathrm{E} 2-------\rightarrow \mathrm{U} \cdot \mathrm{n}-1 \rightarrow \mathrm{Un}$

のように行われる。従って，ユニバーサル压延，エッジャ 圧延，エッジャ圧延後のユニバーサル圧延の 3 ステージに 区分して基本方程式を以下のように求めた。

$2 \cdot 1$ ユニバーサル圧延 (Fig. 3 参照)

$2 \cdot 1 \cdot 1$ 圧延条件とフランジ幅広がりの関係 ${ }^{112)}$

$$
\lambda_{\mathrm{B} 1}=\alpha\left(\lambda_{\mathrm{F} 1}-\lambda_{\mathrm{W} 1}\right)-\beta
$$

中成 4 年: 7 月16 月受付 中成 4 年12月 8 日受理 (Received on July 16, 1992; Accepted on Dec. 8, 1992)

* NKK総令材料技術研究所 (Materials and Processing Research Center, NKK Corporation, 1-1 Minamiwatarida-cho Kawasaki-ku Kawasaki 210)

* 2 NKK福旧彆鉄所 (Fukuyama Works, NKK Corporation)

* 3 (株)エヌ・ケー・エクサ (NK-Exa Co., Ltd.) 


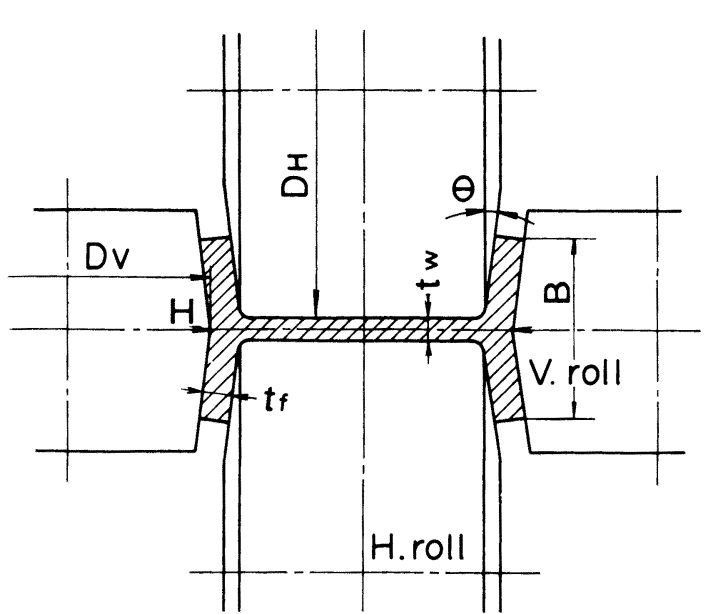

Fig. 1. Universal mill.

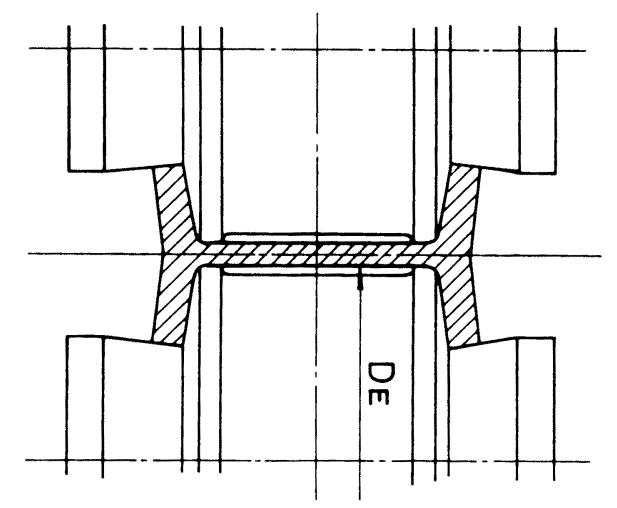

Fig. 2. Edger.

$$
\begin{aligned}
& \lambda_{\mathrm{B} 1}=\ln \left(\mathrm{B}_{1} / \mathrm{B}_{2}\right) \ldots \ldots \ldots \ldots \ldots \\
& \lambda_{\mathrm{F} 1}=\ln \left(\mathrm{t}_{\mathrm{m} 2} / \mathrm{t}_{\mathrm{m} 1}\right) \ldots \ldots \ldots \ldots \ldots \ldots \\
& \lambda_{\mathrm{W} 1}=\ln \left(\mathrm{t}_{\mathrm{W} 2} / \mathrm{t}_{\mathrm{W} 1}\right) \\
& \alpha=0.14 \mathrm{H}^{*} / \mathrm{B}^{*}-0.0056 \ldots \ldots \ldots \ldots \\
& \beta=\left(0.018 \mathrm{~B}^{*}-0.88\right) \times 10^{-3}
\end{aligned}
$$

であり， $\alpha, \beta$ は鉛モデル実験より定めた ${ }^{12)}$ 。これを一般形

\section{として}

$\phi\left(B_{2}, t_{m 2}, t_{m 1}, t_{w 2}, t_{w 1}, B_{1}\right)=0$

とおく。

$2 \cdot 1 \cdot 2$ 平均フランジ厚の定義

$$
\begin{aligned}
& t_{\mathrm{m} 2}=\left(t_{\mathrm{DU} 2}+t_{\mathrm{DL} 2}+t_{\mathrm{FU} 2}+t_{\mathrm{FL} 2}\right) / 4 \\
& \mathrm{t}_{\mathrm{m} 1}=\left(\mathrm{t}_{\mathrm{DU} 1}+\mathrm{t}_{\mathrm{DL} 1}+\mathrm{t}_{\mathrm{FU} 1}+\mathrm{t}_{\mathrm{FL} 1}\right) / 4
\end{aligned}
$$

$2 \cdot 1 \cdot 3$ 圧延条件とロール出側ウェブ厚の関係 ${ }^{122) 788)}$

$$
\begin{aligned}
& \mathrm{P}_{\mathrm{H} 1}=\mathrm{Q}_{\mathrm{H} 1} \cdot \mathrm{P}_{\mathrm{H} 01}+\psi \mathrm{P}_{\mathrm{V} 1} \\
& \mathrm{P}_{\mathrm{V} 1}=\mathrm{Q}_{\mathrm{V} 1} \cdot \mathrm{P}_{\mathrm{V} 01} \cdots \ldots \ldots \ldots
\end{aligned}
$$

ここで

$$
\mathrm{Q}_{\mathrm{H} 1}=1.338-10.66 \mathrm{~A}_{\mathrm{F} 2} /\left(\mathrm{A}_{\mathrm{F} 2}+\mathrm{A}_{\mathrm{W} 2}\right) \cdot\left(\lambda_{\mathrm{F} 1}-\lambda_{\mathrm{W} 1}\right)
$$

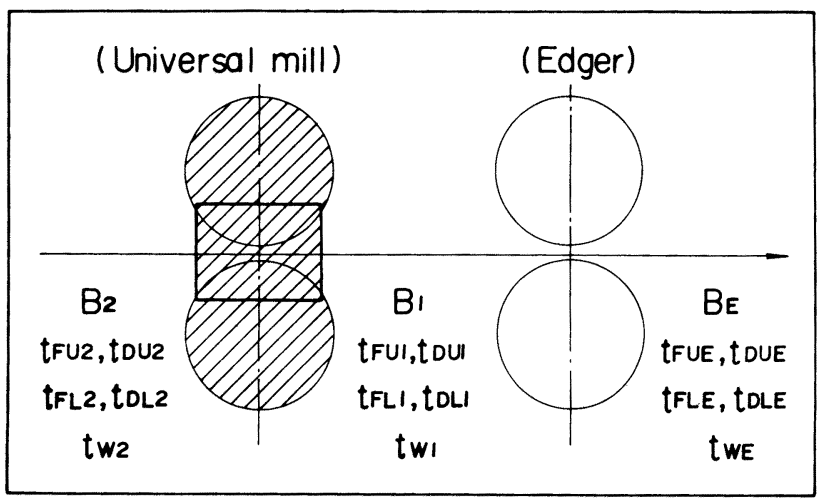

Fig. 3. 1st stage; universal rolling.

$$
\mathrm{Q}_{\mathrm{V} 1}=0.764+1.434 \mathrm{~A}_{\mathrm{W} 2} /\left(\mathrm{A}_{\mathrm{F} 2}+\mathrm{A}_{\mathrm{W} 2}\right) \cdot\left(\lambda_{\mathrm{F} 1}-\lambda_{\mathrm{W} 1}\right)
$$

でありこれらの係数は鉛モデル実験より定めた112)。また， ゲージメータ式として

$$
\mathrm{t}_{\mathrm{W} 1}=\mathrm{S}_{\mathrm{H} 1}+\mathrm{P}_{\mathrm{H} 1} / \mathrm{K}_{\mathrm{H}}
$$

が成立する。(10)〜 (14) 式を一般形として

$$
t_{\mathrm{w} 1}=t_{\mathrm{w}_{1}}\left(\mathrm{~S}_{\mathrm{H} 1}, \mathrm{t}_{\mathrm{m} 2}, \mathrm{t}_{\mathrm{m} 1}, \mathrm{t}_{\mathrm{w} 2}\right)
$$

とおく。

$2 \cdot 1 \cdot 4$ 压延条件とロール出側フランジ厚の関係 ${ }^{122) 718)}$

$$
\mathrm{P}_{\mathrm{VDU} 1}=\mathrm{Q}_{\mathrm{VDU} 1} \cdot \mathrm{P}_{\mathrm{VODU} 1}
$$

同様に, $\mathrm{P}_{\mathrm{VDL} 1}, \mathrm{P}_{\mathrm{VFU} 1}, \mathrm{P}_{\mathrm{VFL1}}$ が成立する。 こご

$$
\mathrm{Q}_{\mathrm{VDU}}=0.764+1.434 \mathrm{~A}_{\mathrm{W} 2} /\left(\mathrm{A}_{\mathrm{F} 2}+\mathrm{A}_{\mathrm{W} 2}\right) \cdot \ln \left(\mathrm{t}_{\mathrm{DU} 2} / \mathrm{t}_{\mathrm{DU} 1} \cdot \mathrm{t}_{\mathrm{W} 1} / \mathrm{t}_{\mathrm{W} 2}\right) \cdots(17)
$$
であり， $\mathrm{Q}_{\mathrm{VDL} 1}, \mathrm{Q}_{\mathrm{VFU1}}, \mathrm{Q}_{\mathrm{VFL1}}$ も同様に表示できる。また， ゲージメータ式として

$$
\begin{aligned}
& \mathrm{t}_{\mathrm{DU} 1}=\mathrm{S}_{\mathrm{DU} 1}+\mathrm{P}_{\mathrm{VDU} 1} / \mathrm{K}_{\mathrm{VD}} \\
& \mathrm{t}_{\mathrm{FU} 1}=\mathrm{S}_{\mathrm{FU} 1}+\mathrm{P}_{\mathrm{VUU} 1} / \mathrm{K}_{\mathrm{VF}}
\end{aligned}
$$

が成立する。 $t_{\mathrm{DL} 1}, \mathrm{t}_{\mathrm{FL} 1}$ も同様に成立する。(16) ～(19)式を 一般形として

$$
t_{D U 1}=t_{D U 1}\left(S_{D U 1}, B_{2}, t_{D U 2}, t_{W 2}, t_{W_{1}}\right)
$$

とおく。 $\mathrm{t}_{\mathrm{DL} 1}, \mathrm{t}_{\mathrm{FU} 1}, \mathrm{t}_{\mathrm{FL} 1}$ も同様である。

$2 \cdot 2$ エッジャ圧延 (Fig. 4 参照)

$2 \cdot 2 \cdot 1$ 圧延条件とロール出側フランジ幅の関係

$$
\mathrm{P}_{\mathrm{E}}=2 \mathrm{k}_{\mathrm{m}} \cdot \mathrm{t}_{\mathrm{m} 1} \cdot \mathrm{1}_{\mathrm{dE}} \cdot \mathrm{Q}_{\mathrm{pE}}
$$

ここで

$$
\begin{aligned}
\mathrm{Q}_{\mathrm{pE}} & =\left(\pi+\mathrm{B}_{\mathrm{mE}} / 1_{\mathrm{dE}}\right) / 4 \\
1_{\mathrm{dE}} & =\sqrt{\mathrm{D}_{\mathrm{E}}\left(\mathrm{B}_{1}-\mathrm{B}_{\mathrm{E}}\right) / 2} \\
\mathrm{~B}_{\mathrm{mE}} & =\left(\mathrm{B}_{1}+2 \mathrm{~B}_{\mathrm{E}}\right) / 3
\end{aligned}
$$




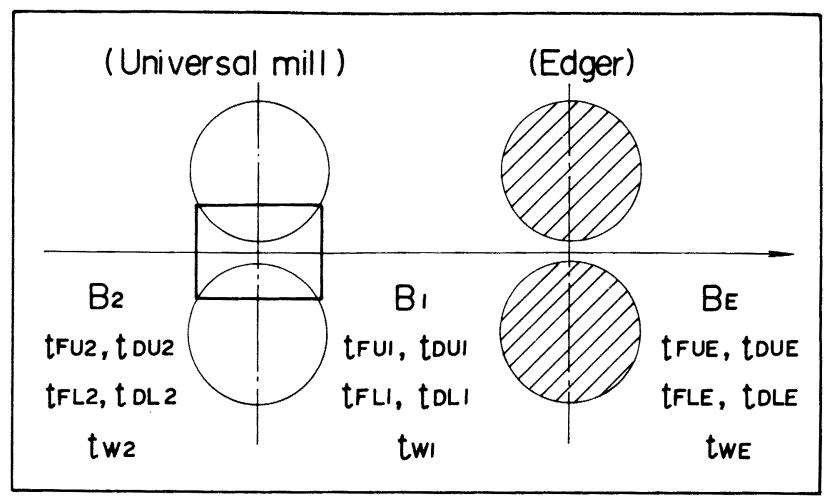

Fig. 4. 2nd stage ; edging.

である。式(22) は熱間圧延の圧下力関数として用いられる 斎藤の式(8)である。また，ゲージメータ式として

$$
\mathrm{B}_{\mathrm{E}}=\mathrm{S}_{\mathrm{E}}+\mathrm{P}_{\mathrm{E}} / \mathrm{K}_{\mathrm{E}}
$$

が成立する。

$2 \cdot 2 \cdot 2$ 压延条件とフランジ厚変化の関係

$$
\ln \left(\mathrm{t}_{\mathrm{DCE}} / \mathrm{t}_{\mathrm{DC} 1}\right)=(1-\gamma) \ln \left(\mathrm{B}_{1} / \mathrm{B}_{\mathrm{E}}\right)
$$

$t_{\mathrm{DLEE}}, \mathrm{t}_{\mathrm{FLE}}, \mathrm{t}_{\mathrm{FLEE}}$ も同様の関係が成立する。

ここで

$\gamma=0.25-0.05 \mathrm{H}^{*} / \mathrm{B}^{*}$

であり，鉛モデル実験より定めた。

$2 \cdot 2 \cdot 3$ 压延条件とウェブ厚变化の関係

$$
\ln \left(\mathrm{t}_{\mathrm{WE}} / \mathrm{t}_{\mathrm{W} 1}\right)=-\gamma \ln \left(\mathrm{B}_{1} / \mathrm{B}_{\mathrm{E}}\right)
$$

\section{$2 \cdot 3$ エッジャ圧延後のユニバーサル圧延 (Fig. 5 参照)}

$2 \cdot 3 \cdot 1$ 压延条件とフランジ幅広がりの関係 ${ }^{12)}$

$$
\lambda_{\mathrm{B} 2}=\alpha\left(\lambda_{\mathrm{F} 2}-\lambda_{\mathrm{W}_{2}}\right)-\beta+\delta
$$

ここで

$$
\begin{aligned}
& \lambda_{\mathrm{B} 2}=\ln \left(\mathrm{B}_{2} / \mathrm{B}_{\mathrm{E}}\right) \\
& \lambda_{\mathrm{F} 2}=\ln \left(\mathrm{t}_{\mathrm{mE}} / \mathrm{t}_{\mathrm{m} 2}\right) \\
& \lambda_{\mathrm{W}_{2}}=\ln \left(\mathrm{t}_{\mathrm{WE}} / \mathrm{t}_{\mathrm{W} 2}\right)
\end{aligned}
$$

である。

$2 \cdot 3 \cdot 2$ 平均フランジ厚の定義

$$
\begin{aligned}
& t_{\mathrm{mE}}=\left(t_{\mathrm{DUE}}+t_{\mathrm{DLE}}+t_{\mathrm{FLE}}+t_{\mathrm{FLE}}\right) / 4 \\
& t_{\mathrm{m} 2}=\left(t_{\mathrm{DU} 2}+t_{\mathrm{DL} 2}+t_{\mathrm{FU} 2}+t_{\mathrm{FL} 2}\right) / 4
\end{aligned}
$$

$2 \cdot 3 \cdot 3$ 圧延条件とロール出側ウェブ厚の関係 ${ }^{122778)}$

$$
\begin{aligned}
& \mathrm{P}_{\mathrm{H} 2}=\mathrm{Q}_{\mathrm{H} 2} \cdot \mathrm{P}_{\mathrm{HO} 2}+\psi \mathrm{P}_{\mathrm{V} 2} \\
& \mathrm{P}_{\mathrm{V}_{2}}=\mathrm{Q}_{\mathrm{V} 2} \cdot \mathrm{P}_{\mathrm{VO} 2} \ldots \ldots \ldots \ldots \ldots
\end{aligned}
$$

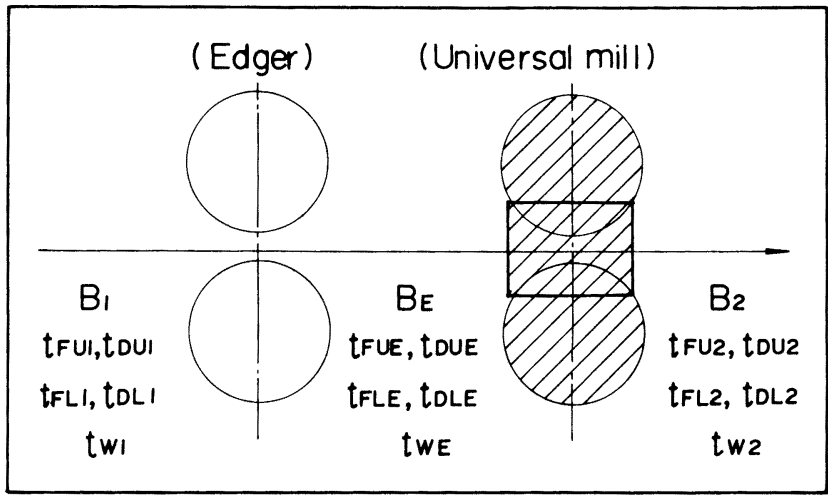

Fig. 5. 3rd stage; universal rolling after edging.

$$
\begin{aligned}
& \mathrm{Q}_{\mathrm{H} 2}=1.338-10.66 \mathrm{~A}_{\mathrm{FE}} /\left(\mathrm{A}_{\mathrm{FE}}+\mathrm{A}_{\mathrm{WE}}\right) \cdot\left(\lambda_{\mathrm{F} 2}-\lambda_{\mathrm{W} 2}\right) \\
& \mathrm{Q}_{\mathrm{V} 2}=0.764+1.434 \mathrm{~A}_{\mathrm{WE}} /\left(\mathrm{A}_{\mathrm{FE}}+\mathrm{A}_{\mathrm{WE}}\right) \cdot\left(\lambda_{\mathrm{F} 2}-\lambda_{\mathrm{W} 2}\right)
\end{aligned}
$$

またゲージメータ式として

$$
\mathrm{t}_{\mathrm{W} 2}=\mathrm{S}_{\mathrm{H} 2}+\mathrm{P}_{\mathrm{H} 2} / \mathrm{K}_{\mathrm{H}}
$$

が成立する。

$2 \cdot 3 \cdot 4$ 圧延条件とロール出側フランジ厚の関係 ${ }^{1122778)}$

$$
\mathrm{P}_{\mathrm{VDU} 2}=\mathrm{Q}_{\mathrm{VDU} 2} \cdot \mathrm{P}_{\mathrm{VODU} 2}
$$

同様に $\mathrm{P}_{\mathrm{VDL} 2}, \mathrm{P}_{\mathrm{VFL} 2}, \mathrm{P}_{\mathrm{VFL} 2}$ が成立する。

ここで

$$
\begin{gathered}
\mathrm{Q}_{\mathrm{VDU} 2}=0.764+1.434 \mathrm{~A}_{\mathrm{WE}} /\left(\mathrm{A}_{\mathrm{FE}}+\mathrm{A}_{\mathrm{WE}}\right) \\
\ln \left(\mathrm{t}_{\mathrm{DLE}} / \mathrm{t}_{\mathrm{DU} 2} \cdot \mathrm{t}_{\mathrm{W} 2} / \mathrm{t}_{\mathrm{WE}}\right) \ldots \ldots \ldots \ldots \ldots \ldots \ldots \ldots \ldots \ldots \ldots \ldots \ldots \ldots
\end{gathered}
$$

であり， $\mathrm{Q}_{\mathrm{VDL} 2}, \mathrm{Q}_{\mathrm{VFU} 2}, \mathrm{Q}_{\mathrm{VFL} 2}$ も同様に表示できる。また, ゲージメータ式として

$$
\begin{aligned}
& t_{\mathrm{DU} 2}=\mathrm{S}_{\mathrm{DU} 2}+\mathrm{P}_{\mathrm{VDU} 2} / \mathrm{K}_{\mathrm{VD}} \\
& \mathrm{t}_{\mathrm{FL} 2}=\mathrm{S}_{\mathrm{FU} 2}+\mathrm{P}_{\mathrm{FDU} 2} / \mathrm{K}_{\mathrm{VF}}
\end{aligned}
$$

が成立する。 $t_{\mathrm{DL} 2}, \mathrm{t}_{\mathrm{FL} 2}$ 同様に成立する。

いま $\mathrm{H}$ 形鋼のユニバーサル圧延において圧延状態に変化 が生じ新しい定常状態に移行した時, 压延条件の変化率は (1)～(44) 式をテーラー展開し 2 次以上の項を無視した基 本方程式を満足しなければならない。2・1のユニバーサル 压延の場合を例として（1)（20)式を変形した結果を以下 に示寸。

$$
\begin{aligned}
& \frac{\mathrm{B}_{2}}{\mathrm{~B}_{1}}\left[\frac{\partial \phi}{\partial \mathrm{B}_{2}}\right]\left[\frac{\Delta \mathrm{B}_{2}}{\mathrm{~B}_{2}}\right]+\frac{\mathrm{t}_{\mathrm{m} 2}}{\mathrm{~B}_{1}}\left[\frac{\partial \phi}{\partial \mathrm{t}_{\mathrm{m} 2}}\right]\left[\frac{\Delta \mathrm{t}_{\mathrm{m} 2}}{\mathrm{t}_{\mathrm{m} 2}}\right] \\
& \quad+\frac{\mathrm{t}_{\mathrm{m} 1}}{\mathrm{~B}_{1}}\left[\frac{\partial \phi}{\partial \mathrm{t}_{\mathrm{m} 1}}\right]\left[\frac{\Delta \mathrm{t}_{\mathrm{m} 1}}{\mathrm{t}_{\mathrm{m} 1}}\right]+\frac{\mathrm{t}_{\mathrm{w} 2}}{\mathrm{~B}_{1}}\left[\frac{\partial \phi}{\partial \mathrm{t}_{\mathrm{w} 2}}\right]\left[\frac{\Delta \mathrm{t}_{\mathrm{w} 2}}{\mathrm{t}_{\mathrm{w} 2}}\right] \\
& +\frac{\mathrm{t}_{\mathrm{w} 1}}{\mathrm{~B}_{1}}\left[\frac{\partial \phi}{\partial \mathrm{t}_{\mathrm{w} 1}}\right]\left[\frac{\Delta \mathrm{t}_{\mathrm{w} 1}}{\mathrm{t}_{\mathrm{w} 1}}\right]+\left[\frac{\partial \phi}{\partial \mathrm{B}_{1}}\right]\left[\frac{\Delta \mathrm{B}_{1}}{\mathrm{~B}_{1}}\right]=0 \cdots \cdots \cdots \\
& \frac{1}{4} \frac{\mathrm{t}_{\mathrm{DU} 2}}{\mathrm{t}_{\mathrm{m} 2}}\left[\frac{\Delta \mathrm{t}_{\mathrm{DU} 2}}{\mathrm{t}_{\mathrm{DU} 2}}\right]+\frac{1}{4} \frac{\mathrm{t}_{\mathrm{DL} 2}}{\mathrm{t}_{\mathrm{m} 2}}\left[\frac{\Delta \mathrm{t}_{\mathrm{DL} 2}}{\mathrm{t}_{\mathrm{DL} 2}}\right]+\frac{1}{4} \frac{\mathrm{t}_{\mathrm{FU} 2}}{\mathrm{t}_{\mathrm{m} 2}}\left[\frac{\Delta \mathrm{t}_{\mathrm{FU} 2}}{\mathrm{t}_{\mathrm{FU} 2}}\right]
\end{aligned}
$$




$$
\begin{aligned}
& +\frac{1}{4} \frac{\mathrm{t}_{\mathrm{FL} 2}}{\mathrm{t}_{\mathrm{m} 2}}\left[\frac{\Delta \mathrm{t}_{\mathrm{FL} 2}}{\mathrm{t}_{\mathrm{FL} 2}}\right]-\left[\frac{\Delta \mathrm{t}_{\mathrm{m} 2}}{\mathrm{t}_{\mathrm{m} 2}}\right]=0 \\
& \frac{1}{4} \frac{t_{\mathrm{DU} 1}}{\mathrm{t}_{\mathrm{m} 1}}\left[\frac{\Delta \mathrm{t}_{\mathrm{DU1}}}{\mathrm{t}_{\mathrm{DU1}}}\right]+\frac{1}{4} \frac{\mathrm{t}_{\mathrm{DL1}}}{\mathrm{t}_{\mathrm{m} 1}}\left[\frac{\Delta \mathrm{t}_{\mathrm{DL} 1}}{\mathrm{t}_{\mathrm{DL} 1}}\right]+\frac{1}{4} \frac{\mathrm{t}_{\mathrm{FU1}}}{\mathrm{t}_{\mathrm{m} 1}}\left[\frac{\Delta \mathrm{t}_{\mathrm{FU1}}}{\mathrm{t}_{\mathrm{FU1}}}\right] \\
& +\frac{1}{4} \frac{t_{\mathrm{FL1}}}{\mathrm{t}_{\mathrm{m} 1}}\left[\frac{\Delta \mathrm{t}_{\mathrm{FL1}}}{\mathrm{t}_{\mathrm{FL} 1}}\right]-\left[\frac{\Delta \mathrm{t}_{\mathrm{m} 1}}{\mathrm{t}_{\mathrm{m} 1}}\right]=0 \\
& \mathrm{a}_{\mathrm{SH} 1}\left[\frac{\Delta \mathrm{S}_{\mathrm{H} 1}}{\mathrm{t}_{\mathrm{w} 1}}\right]+\mathrm{a}_{\mathrm{tm} 2}\left[\frac{\Delta \mathrm{t}_{\mathrm{m} 2}}{\mathrm{t}_{\mathrm{m} 2}}\right]+\mathrm{a}_{\mathrm{tm} 1}+\left[\frac{\Delta \mathrm{t}_{\mathrm{m} 1}}{\mathrm{t}_{\mathrm{m} 1}}\right] \\
& +\mathrm{a}_{\mathrm{tw2}}\left[\frac{\Delta \mathrm{t}_{\mathrm{w} 2}}{\mathrm{t}_{\mathrm{w} 2}}\right]-\left[\frac{\Delta \mathrm{t}_{\mathrm{w} 1}}{\mathrm{t}_{\mathrm{w} 1}}\right]=0
\end{aligned}
$$

ここで

$$
\begin{aligned}
\mathrm{a}_{\mathrm{SH} 1} & =\frac{\mathrm{K}_{\mathrm{H}}}{\mathrm{K}_{\mathrm{H}}-\partial \mathrm{P}_{\mathrm{H} 1} / \partial \mathrm{t}_{\mathrm{w} 1}} \cdots \cdots \ldots . . . . . \\
\mathrm{a}_{\mathrm{tm} 2} & =\frac{\partial \mathrm{P}_{\mathrm{H} 1} / \partial \mathrm{t}_{\mathrm{m} 2}}{\mathrm{~K}_{\mathrm{H}}-\partial \mathrm{P}_{\mathrm{H} 1} / \partial \mathrm{t}_{\mathrm{w} 1}} \cdot \frac{\mathrm{t}_{\mathrm{m} 2}}{\mathrm{t}_{\mathrm{w} 1}} \\
\mathrm{a}_{\mathrm{tm} 1} & =\frac{\partial \mathrm{P}_{\mathrm{H} 1} / \partial \mathrm{t}_{\mathrm{m} 1}}{\mathrm{~K}_{\mathrm{H}}-\partial \mathrm{P}_{\mathrm{H} 1} / \partial \mathrm{t}_{\mathrm{w} 1}} \cdot \frac{\mathrm{t}_{\mathrm{m} 1}}{\mathrm{t}_{\mathrm{w} 1}} \\
\mathrm{a}_{\mathrm{tw} 2} & =\frac{\partial \mathrm{P}_{\mathrm{H} 1} / \partial \mathrm{t}_{\mathrm{w} 2}}{\mathrm{~K}_{\mathrm{H}}-\partial \mathrm{P}_{\mathrm{H} 1} / \partial \mathrm{t}_{\mathrm{w} 1}} \cdot \frac{\mathrm{t}_{\mathrm{w} 2}}{\mathrm{t}_{\mathrm{w} 1}}
\end{aligned}
$$

と求まる。

$$
\begin{gathered}
\mathrm{b}_{\mathrm{SDU} 1}\left[\frac{\Delta \mathrm{S}_{\mathrm{DU} 1}}{\mathrm{t}_{\mathrm{DU} 1}}\right]+\mathrm{b}_{\mathrm{B} 2}\left[\frac{\Delta \mathrm{B}_{2}}{\mathrm{~B}_{2}}\right]+\mathrm{b}_{\mathrm{tDU} 2}\left[\frac{\Delta \mathrm{t}_{\mathrm{DU} 2}}{\mathrm{t}_{\mathrm{DU} 2}}\right] \\
+\mathrm{b}_{\mathrm{tw} 2}\left[\frac{\Delta \mathrm{t}_{\mathrm{w} 2}}{\mathrm{t}_{\mathrm{w} 2}}\right]+\mathrm{b}_{\mathrm{tw} 1}\left[\frac{\Delta \mathrm{t}_{\mathrm{w} 1}}{\mathrm{t}_{\mathrm{w} 1}}\right]-\left[\frac{\Delta \mathrm{t}_{\mathrm{DU} 1}}{\mathrm{t}_{\mathrm{DU} 1}}\right]=0
\end{gathered}
$$

(53) 式の係数は (49) ～(52) 式と同様に求められる。また, (45)～(53) 式の 1 次項のみを取り出した係数は, 前述して きたように鉛モデル圧延実験結果を主にして作成した数式 モデルより容易に求めることができる。以上の展開を $2 \cdot 2$ エッジャ圧延, $2 \cdot 3$ エッジャ圧延後のユニバーサル压延 に適用することにより全ての基本方程式が求まる。

\section{3. 解析}

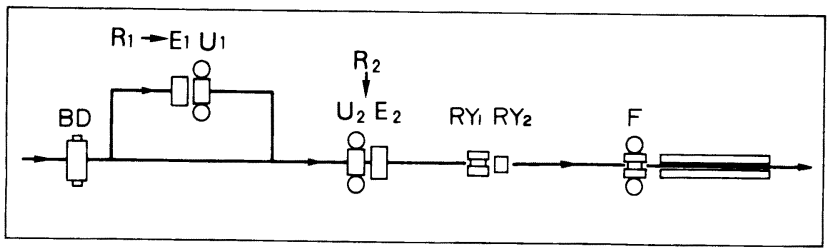

Fig. 6. The layout of Fukuyama Works No.1 Large Shape Mill, (BD:Break down mill, $R_{1}:$ No.1 roghing mill, $R_{2}:$ No.2 roughing mill, $U_{1}, U_{2}$ : Universal mill, $\mathrm{E}_{1}, \mathrm{E}_{2}$ :Edger, $\mathrm{RY}_{1}, \mathrm{RY}_{2}: \mathrm{Web}$ widening mill, $F$ :Finishing universal mill).

Table 1. $R_{2}$ Mill specifications.

\begin{tabular}{c|c|c|c|c}
\hline \multicolumn{2}{c|}{ Mill } & Roll diameter $(\mathrm{mm})$ & $\begin{array}{l}\text { Motor } \\
\text { capacity }(\mathrm{kw})\end{array}$ & $\begin{array}{l}\text { Rolling } \\
\text { speed (rpm) }\end{array}$ \\
\hline \multirow{2}{*}{$\mathrm{R}_{2}$} & \multirow{2}{*}{$\mathrm{U}_{2}$} & H. roll $: 1575 \sim 1255$ & \multirow{2}{*}{ DC6000 } & $65 / 150$ \\
\cline { 2 - 3 } & & V. roll $: 1070 \sim 740$ & & \\
\cline { 2 - 5 } & $\mathrm{E}_{2}$ & $1040 \sim 780$ & DC1100 $\times 2$ & $150 / 340$ \\
\hline
\end{tabular}

Fig. 6 に示寸福山第 1 大形工場の第 2 粗圧延機群 $\left(\mathrm{R}_{2}\right.$ ミ ル）での H形鋼圧延を対象に影響係数法による総合特性の 解析ならびに制御則導出のためのシミュレーション計算を 行った。計算は対象サイズを $\mathrm{H} 300 \times 300 \times 10 / 15, H 500 \times$ $200 \times 10 / 16$ とし,

$\mathrm{U}_{2} 1$ (ユニバーサルミル 1 パス目) $\rightarrow \mathrm{E}_{2} 1$ (エッジャ 1 パス 目) $\rightarrow \mathrm{U}_{2} 2 \rightarrow \mathrm{U}_{2} 3 \rightarrow \mathrm{E}_{2} 2 \rightarrow \mathrm{U}_{2} 4 \rightarrow \mathrm{U}_{2} 5$ のユニバーサル 5 パス圧 延とした。Table 1 に趾ミルの主仕様走示寸。

$3 \cdot 1$ 圧延条件の変化がユニバーサル 5 パス圧延後の被圧 延材寸法に及ぼす影響〔総合特性〕

独立変 数

i パス目入側各部寸法変化量

i パス目以降各パスミルロールギャップ変化量

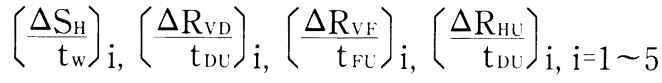

$\left(\frac{\Delta \mathrm{S}_{\mathrm{E}}}{\mathrm{B}_{\mathrm{E}}}\right)$

$\left(\frac{\Delta \mathrm{S}_{\mathrm{E}}}{\mathrm{B}_{\mathrm{E}}}\right)_{\mathrm{i}, \mathrm{i}=1,2}$

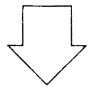

従 属 変 数

5 パス压延後の各部寸法変化量

$$
\begin{aligned}
& \left(\frac{\Delta \mathrm{t}_{\mathrm{w}}}{\mathrm{t}_{\mathrm{w}}}\right)_{5},\left(\frac{\Delta \mathrm{t}_{\mathrm{DU}}}{\mathrm{t}_{\mathrm{DU}}}\right)_{5},\left(\frac{\Delta \mathrm{t}_{\mathrm{DL}}}{\mathrm{t}_{\mathrm{DL}}}\right)_{5} \\
& \left(\frac{\Delta \mathrm{t}_{\mathrm{FU}}}{\mathrm{t}_{\mathrm{FU}}}\right)_{5},\left(\frac{\Delta \mathrm{t}_{\mathrm{FL}}}{\mathrm{t}_{\mathrm{FL}}}\right)_{5},\left(\frac{\Delta \mathrm{B}}{\mathrm{B}}\right)_{5}
\end{aligned}
$$

上記のように变数を分類して基本方程式を解くと各パス ロールギャップ変化量がユニバーサルミルの5 パス目の最 終出側寸法に及ぼす影響係数 $\alpha^{K}$ が浗まる。ここでははパスNo,

Kは寸法の注目位置を示寸。Fig. 7 にュニバーサルミル各パ スの水平ロールギャップ変化が 5 パス压延後のウェブ厚に 及ぼす影響を解析例として示す。水平ロールギヤップが増 大寸ると 5 パス压延後のウェブ厚の増大となってあらわれ その影響度は後段パス程大きくなることがわかる。これら の解析を総合した結果をFig. 8 ～Fig.11に示寸。Fig. 8 は土 ニバーサルミル各パスの水平ロールギャップ変化がユニバ 一サル 5 パス压延後の被压延材寸法に及ぼす影響である。 水平ロールギャップ変化が直接影響する部位であるウェブ 厚(図中の $\mathrm{K}=1$ ) への影響度合は大きいが直接影響しない 部位のフランジ厚(図中の $\mathrm{K}=2 \sim 5$ ) ならびにフランジ幅 (図中の $\mathrm{K}=6$ ) への影響は小さい。但し，フランジ幅の变 化の絶対值は寸法精度上見逃せない值である。

Fig. 9 はユニバーサルミル各パスのドライブ側竪ロール(図 中の(D) ギャップ変化がユニバーサル5 パス压延後の被圧 延材寸法に及ぼす影響を示寸。Fig. 8 の結果と同様ドライブ 側竪ロールギャップ変化が直接影響する部位のドライブ側 


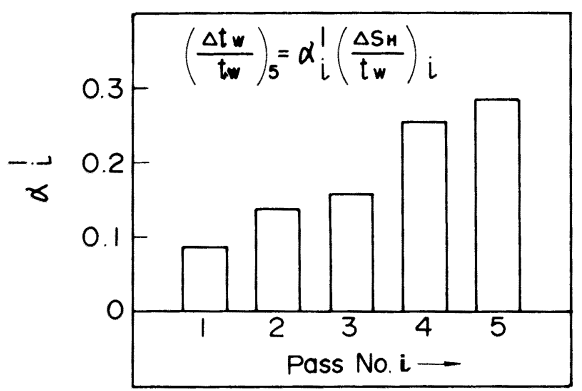

Fig. 7. The influence of change in horizontal roll gap at each pass of universal mill on the web thickness after 5 passes in universal rolling. $(\mathrm{H} 300 \times 300 \times 10 / 15)$

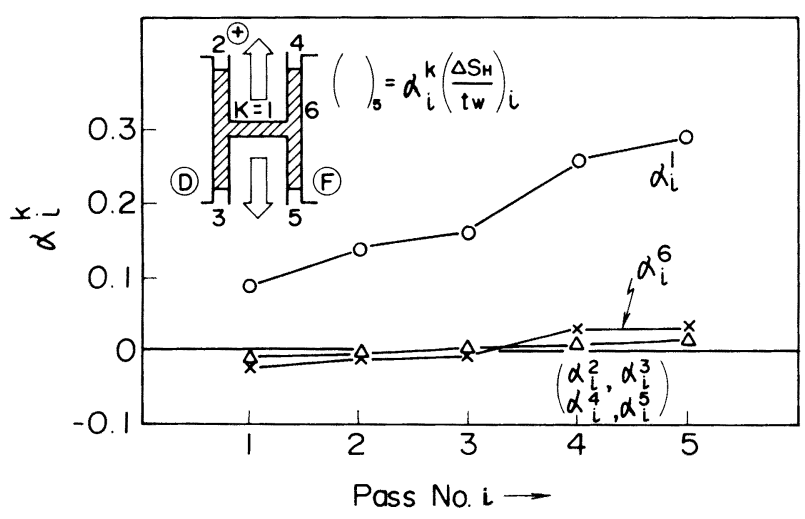

Fig. 8. The influence of change in horizontal roll gap at each pass of universal mill on the rolling demensions after 5 passes in universal rolling. $(\mathrm{H} 300 \times 300 \times 10 / 15)$

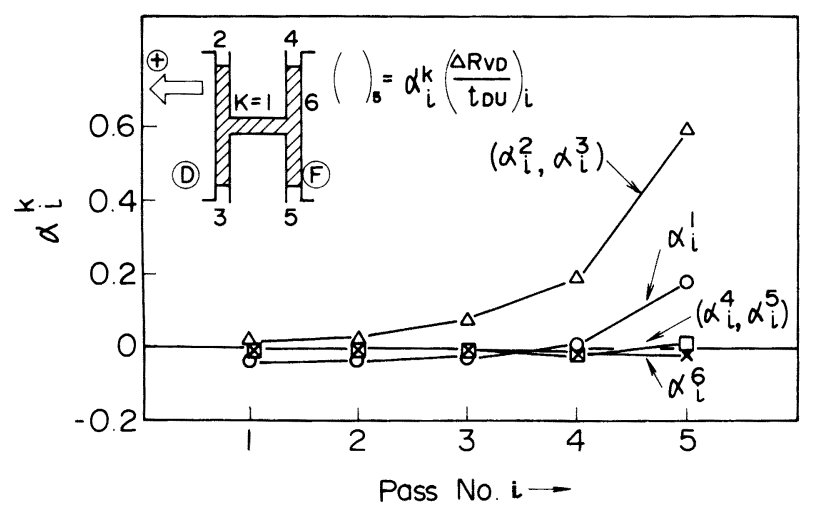

Fig. 9. The influence of change in vertical roll gap at drive side at each pass of universal mill on the rolling demensions after 5 passes in universal rolling. $(\mathrm{H} 300 \times 300 \times 10 / 15)$

フランジ厚への影響度合が大きく後段パスになるに従い影 響が漸増する。直接影響しない部位のウエブ厚に対しては 4 パス目までの影響は小さいが，最終 5 パスにおいては， ドライブ側㹂ロールギャップが増大するとウェブ部に圧縮 応力が作用することによる水平ロール荷重の増加によって, ウェブ厚が増大寸る影響が若干大きく残存する。一方，直 接影響しない他の部位のフリー側フランジ厚ならびにフラ

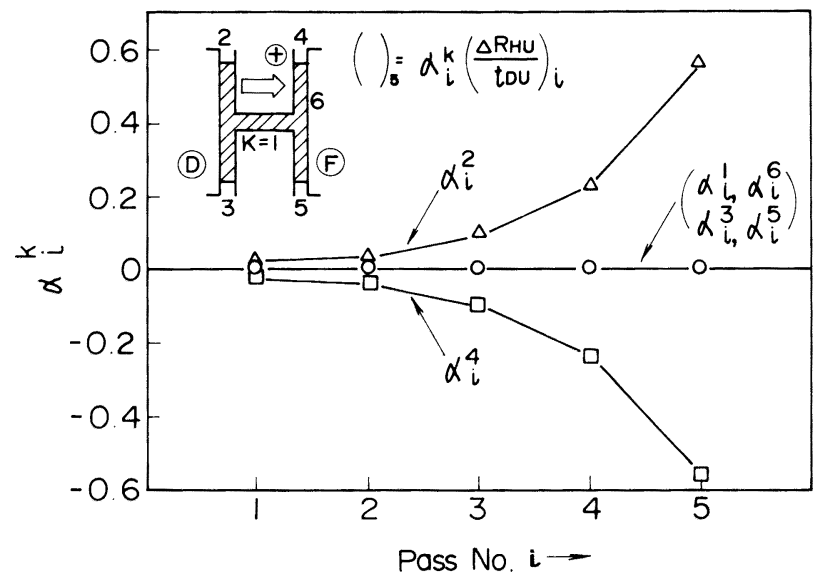

Fig. 10. The influence of change in horizontal roll movement in the derection of axis at each pass of universal mill on the rolling demensions after 5 passes in universal rolling. $(\mathrm{H} 300 \times 300 \times 10 / 15)$

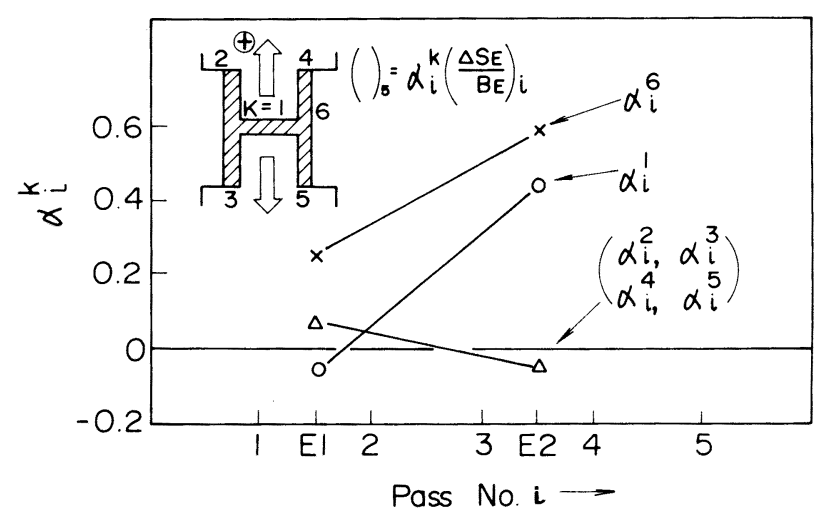

Fig. 11. The influence of change in edging roll gap at each pass of edger on the rolling demensions after 5 passes in universal rolling. $(\mathrm{H} 300 \times 300 \times 10 / 15)$

ンジ幅への影響度合は小さい。前述と同様フランジ幅の変 化の絶対值は問題である。

ユニバーサルミル各パスの上水平ロールの軸方向への調 整量が変化した場合のユニバーサル5パス压延後の被压延 材寸法に及ぼす影響を示したのがFig.10である。この場合も， 上水平ロールの軸方向への調整量の変化が直接影響する部 位であるドライブ側およびフリ一側上フランジ厚への影響 度合が大きく後段パスになるに従い漸増する。直接影響し ない部位のウェブ厚, ドライブ側・フリー側下フランジ厚 ならびにフランジ幅への影響度合は非常に小さい。

Fig.11はエッジャ各パスのロールギャップ変化がユニバー サル 5 パス圧延後の被圧延材寸法に及ばす影響を示寸。工 ッジャロールギャップ変化の影響も直接影響する部位であ るフランジ幅への影響度合が大きく後段パス程大きい。ま た，この場合は直接影響しない部位であるウェブ厚への影 響度合も後段で相当大きくなる。直接影響しない他の部位 のフランジ厚への影響は小さい。Fig. 8 Ｆig.11の結果にお いて，直接影響しない部位への影響度合は，ロールギャッ 
プ変化を生じるパスにより逆転する傾向が見られる。

\section{$3 \cdot 2$ 寸法制御の為のロールギャップ修正量〔制御則〕}

独立 変 数

i パス目入側各部寸法変化量

5 パス圧延後の各部寸法変化量

$$
\begin{aligned}
& \left(\frac{\Delta \mathrm{t}_{\mathrm{w}}}{\mathrm{t}_{\mathrm{w}}}\right)_{5,},\left(\frac{\Delta \mathrm{t}_{\mathrm{DU}}}{\mathrm{t}_{\mathrm{DU}}}\right)_{5},\left(\frac{\Delta \mathrm{t}_{\mathrm{DL}}}{\mathrm{t}_{\mathrm{DL}}}\right)_{5} \\
& \left(\frac{\Delta \mathrm{t}_{\mathrm{FU}}}{\mathrm{t}_{\mathrm{FU}}}\right)_{5,},\left(\frac{\Delta \mathrm{t}_{\mathrm{FL}}}{\mathrm{t}_{\mathrm{FL}}}\right)_{5},\left(\frac{\Delta \mathrm{B}}{\mathrm{B}}\right)_{5}
\end{aligned}
$$

従 属 変 数

i パス目以降全パスミルロールギャップ修正量

$\left(\frac{\Delta \mathrm{S}_{\mathrm{H}}}{\mathrm{t}_{\mathrm{w}}}\right)_{\mathrm{i},}\left(\frac{\Delta \mathrm{R}_{\mathrm{VD}}}{\mathrm{t}_{\mathrm{DU}}}\right)_{\mathrm{i},}\left(\frac{\Delta \mathrm{R}_{\mathrm{VF}}}{\mathrm{t}_{\mathrm{Fu}}}\right)_{\mathrm{i}},\left(\frac{\Delta \mathrm{R}_{\mathrm{HU}}}{\mathrm{t}_{\mathrm{DU}}}\right)_{\mathrm{i}, \mathrm{i}=1 \sim 5}$

$\left(\Delta \mathrm{S}_{\mathrm{E}}\right)$

$\left(\frac{\Delta \mathrm{S}_{\mathrm{E}}}{\mathrm{B}_{\mathrm{E}}}\right)_{\mathrm{i}, \mathrm{i}=1,2}$

上記のように変数を分類して基本方程式を解くとユニバ 一サル 5 パス压延後の被圧延材各部の寸法変化量に対する 冬ミルのロールギャップ修正量が求まる。ここでは，1パ スの修正量を小さくするため全パスで修正を行う事とし， 基本パススケジュールに沿って一定の割合で漸減させる拘 束条件を入れることにより解析した。なお，4点のフラン ジ厚の内， 1 点は物理的に制御不能であり本解析ではドラ イブ側下フランジ厚をその対象とした。この計算結果をFig. 12〜 Fig.15に示す。

Fig.12はユニバーサル 5 パス圧延後の被圧延材ウェブ厚を 增大させ他の部位は変化させない場合である。ウェブ厚を 全パスで増大させるにはユニバーサルミルの水平ロールギ ヤップ(忷中のK=1) を徐々に増大させる必要がある。こ のギャップ増加によりフランジ部には圧縮応力が生じ堅口 一ル荷重が増大してフランジ厚が増大寸る。このため四示 の結果は，竪ロールギャップ(网中の $\mathrm{K}=2 ， 3$ ) を閉め込 むことにより所定のフランジ厚を確保する必要があること

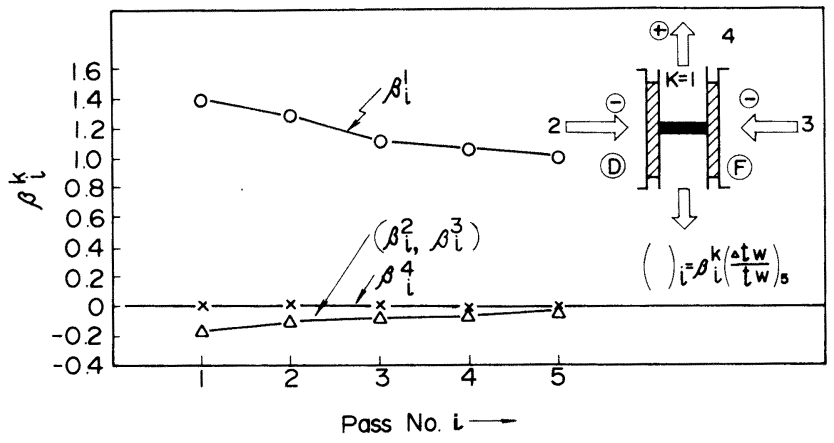

Fig. 12. The roll gap adjustment for increasing web thickness after 5 passes in universal rolling. $(\mathrm{H} 500 \times 200 \times 10 / 16)$
を示している。ここで上水平ロール軸調整(忷中のK=4) は不要である。

Fig.13はドライブ側上フランジ厚を増大させ他の部位は変 化させない場合を示す。このためにはまずドライブ側堅口 ール (図中の(D) ギャップを全パスで増大させることが必要 となる。しかしこれによる水平ロール荷重の増大により口 一ルギャップとウェブ厚が増大するため, 水平ロールギャ ップを閉め込むことによりウェブ厚を所定寸法とする。な お，この場合フリー側竪ロール(図中の(F) ギャップ調整お よび上水平ロール軸調整は不要である。

次に，ユニバーサル 5 パス圧延後の被圧延材フリ一側上 フランジ厚を増大させる場合の結果をFig.14に示す。この場 合にはまず上水平ロール軸調整によりフリー側上フランジ 厚を増大させる。次に，ドライブ側竪ロールギャップを増 大しドライブ側上フランジ厚の所定寸法を確保する。この 結果としてFig.13と同様の理由でウェブ厚を所定寸法とする ための水平ロールギャップの閉め込みが必要となる。フリ 一側堅ロールギャップ調整は不要である。

Fig.15はユニバーサル 5 パス圧延後の被圧延材のフリー側 下フランジ厚を増大させる場合を示す。このためには, フ リ一側竪ロールギャップを增大させるが, フリー側上フラ ンジ厚を所定寸法に確保する必要から上水平ロールの軸詓 整も行う。次いでドライブ側上フランジ厚を所定寸法とす

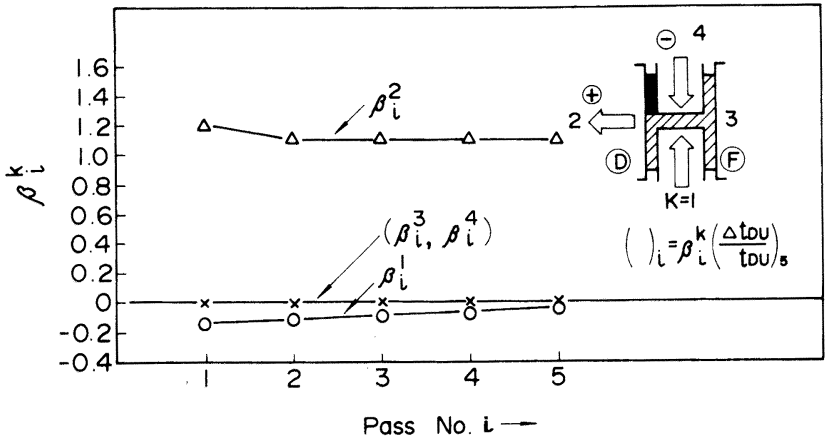

Fig. 13. The roll gap adjustment for increasing upper flange thickness at drive side after 5 passes in universal rolling. $(\mathrm{H} 500 \times 200 \times 10 /$ 16)

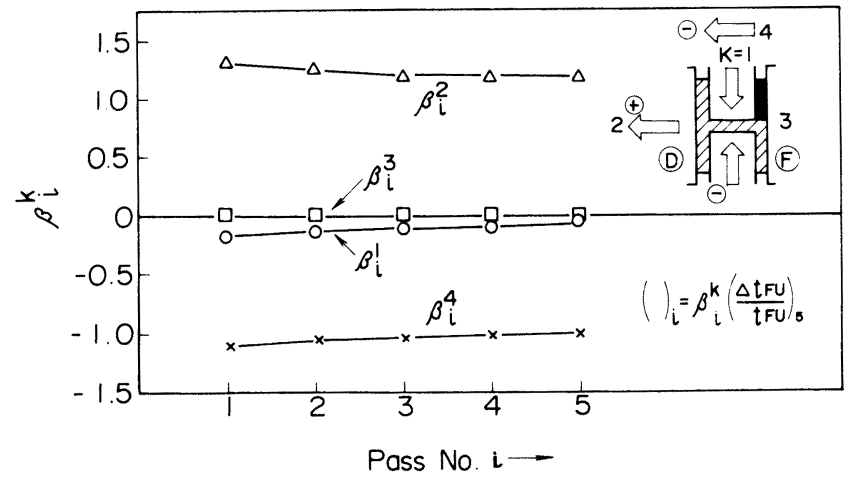

Fig. 14. The roll gap adjustment for increasing upper flange thickness at free side after 5 passes in universal rolling. $(\mathrm{H} 500 \times 200 \times 10 /$ 16) 


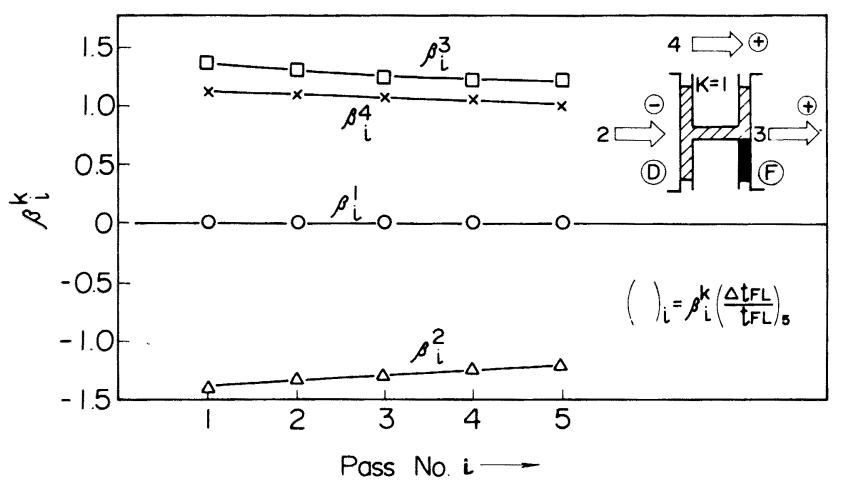

Fig. 15. The roll gap adjustment for increasing lower flange thickness at free side after 5 passes in universal rolling. $(\mathrm{H} 500 \times 200 \times 10 /$ 16)

るためドライブ側竪ロールのギャップ閉め込みが必要とな る。水平ロールギャップ調整は不要である。なお, Fig.12〜 Fig. 15の結果において制御不能の対象としたドライブ側下フラ ンジ厚に対する影響度を考慮する必要がある。

これらの計算結果に示されたように，ロールギャップ修 正量を压延状態を変えないように基本パススケジュールに 比例させることにより，実操業上無理のない各パスロール ギャップ修正が可能となる。また，各パスロールギャップ 修正の拘束条件を変えることによりパス間の修正量を任意 に変更することも可能である。

\section{4. 実機適用}

以上のように影響係数法から求めた制御則を福山第 1 大 形工場のH形鈰圧延に適用した。そのシステム概要をFig. 16 に示寸。ここで実績データは現在のところではホットッー サンプルの測定結果である。この実用化においてユニバー サルミルの上水平ロール軸調整装置9を新たに導入した。こ の装置の概要をFig. 17に示す。四示のとおり本装置は油㞋 シリンダーの上下運動をテーパにより軸方向運動に変換し, ヨークおよびチョックを介して上水平ロールを軸方向へ制 御する構造を有している。なおこの装置の軸方向作動量は土 $3 \mathrm{~mm}$ である。

本影響係数法の適用結果の例をFig. 18に示寸がウェブ厚, フランジ厚, フランジ幅とも大幅に目標值に近づいている。 とりわけユニバーサルミルの上水平ロール軸調整装置の導 入によりフランジ厚の 4 ヶ所間の差(偏肉)が減少している のが注目される。

\section{5. 結言}

$\mathrm{H}$ 形鋼のユニバーサルミルおよびエッジャによる複数レバ 一ス圧延は多数の圧延因子が相互に影響し合い寸法の調整 を困難にしていた。この問題を解決すべ影響係数法によ って総合特性の解析を行うと共に新しい制御則を確立した。

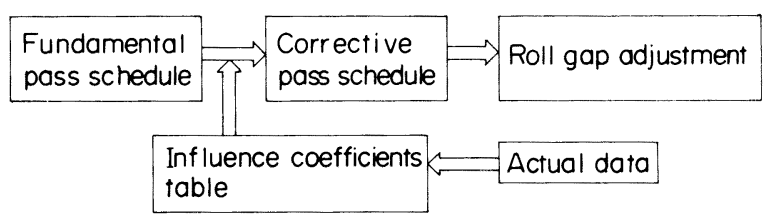

Fig. 16. The scheme of rolling dimensions control system for $\mathrm{H}$-beams.

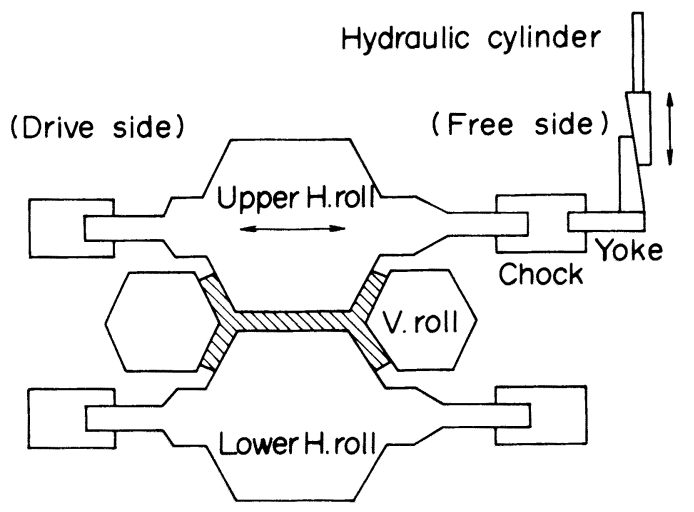

Fig. 17. The scheme of horizontal roll movement in the direction of axis.

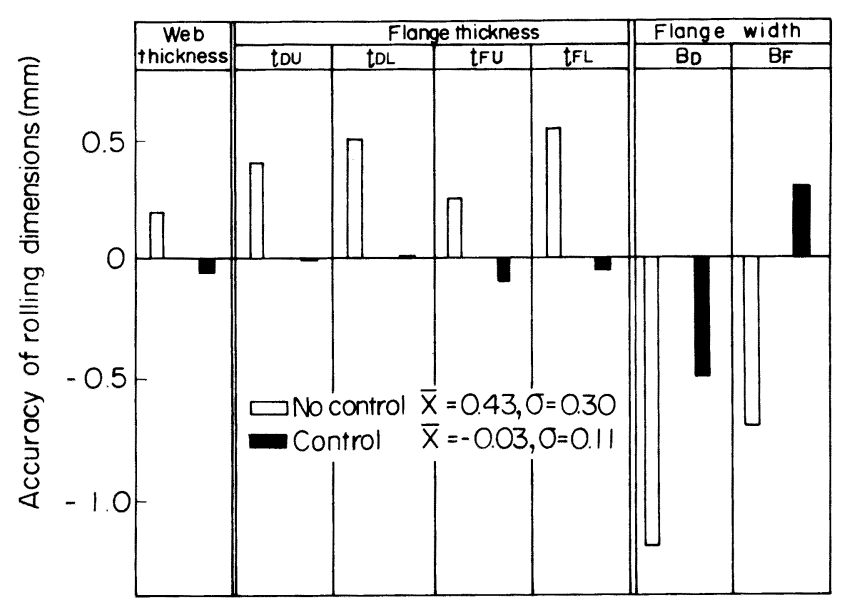

Fig. 18. The effect of application of the influence coefficients method to actual mill.(H450X $200 \times 9 / 14)$

その結果を踏まえ，ユニバーサルミルの上水平ロールの軸 調整装置の開発を行い本制御方法を実機に適用した結果, H形䤱の压延寸法精度の向上に本法が有効であることが磼認 された。今後活压延オンラインでの厚さ，幅計測技術の開 発と並行し，パス間での寸法制御法を確立し一層の寸法精 度向上を図る計画である。

$\begin{array}{ll} & \\ t_{W} & : \text { ウェブ厚 } \\ t_{f} & : \text { フランジ厚 } \\ t_{D U} & : \text { ドライブ側上フランジ厚 } \\ t_{D L} & : \text { ドライブ側下フランジ厚 } \\ t_{F U} & : \text { フリー側上フランジ厚 }\end{array}$


$t_{\mathrm{FL}}$ : フリー側下フランジ厚

$\mathrm{t}_{\mathrm{m}}$ : 平均フランジ厚

$\mathrm{A}_{\mathrm{W}}$ : ウェブ断面積

$\mathrm{A}_{\mathrm{F}}$ ：フランジ断面積

$\mathrm{H}$ : ウェブ高さ

$\mathrm{H}^{*}$ : 呼称ウェブ高さ

B : フランジ幅

$\mathrm{B}^{*}$ : 呼称フランジ幅

$\mathrm{S}_{\mathrm{H}} \quad$ : 水平ロールギャップ

$\mathrm{S}_{\mathrm{DU}}$ ：ドライブ側竪ロール上ギャップ

$\mathrm{S}_{\mathrm{FU}}$ ：フリ一側竪ロール上ギャップ

$\mathrm{R}_{\mathrm{HU}}$ : 上水平ロール軸調整量

$\mathrm{R}_{\mathrm{VD}}$ ：ドライブ側竪ロール調整量

$\mathrm{R}_{\mathrm{VF}}$ ：フリ一側竪ロール調整量

$\mathrm{S}_{\mathrm{E}} \quad$ : エッジャロールギャップ

$\mathrm{D}_{\mathrm{H}}$ : 水平ロール径

$\mathrm{D}_{\mathrm{v}}$ ：堅ロール径

$\mathrm{D}_{\mathrm{E}} \quad$ : エッジャロール径

$\theta$ ：ロール面テーパ角度

$\lambda_{\mathrm{w}}$ : ウェブ压下率

$\lambda_{\mathrm{F}}:$ : フランジ圧下率

$\lambda_{\mathrm{B}} \quad$ : フランジ幅広がり率

$\mathrm{P}_{\mathrm{H}}$ : 水平ロール圧延荷重

$\mathrm{P}_{\mathrm{V}}$ ：堅ロール圧延荷重

$\mathrm{P}_{\mathrm{VDU}}$ ：ドライブ側竪ロール上圧延荷重

$\mathrm{P}_{\mathrm{VDL}}$ ：ドライブ側竪ロール下圧延荷重

$\mathrm{P}_{\mathrm{VFU}}$ : フリー側竪ロール上圧延荷重

$\mathrm{P}_{\mathrm{VFL}}$ : フリー側竪ロール下圧延荷重

$\mathrm{P}_{\mathrm{HO}}$ ：ウェブの等価な板圧延荷重
$\mathrm{P}_{\mathrm{vo}}$ : フランジの等価な板圧延荷重

$\mathrm{P}_{\text {VODU }}$ ：ドライブ側上フランジの等価な板庄延荷重

$\psi$ : 竪ロール圧延荷重からの分力係数 $(=\tan \theta)$

$\mathrm{Q}_{\mathrm{H}}$ : 水平ロール压延荷重補正係数

$Q_{V}$ ：竪ロール圧延荷重補正係数

$\mathrm{Q}_{\mathrm{VDU}}$ ：ドライブ側堅ロール上圧延荷重補正係数

$\mathrm{Q}_{\mathrm{VDL}}$ ：ドライブ側竪ロール下圧延荷重補正係数

$\mathrm{Q}_{\mathrm{VFU}}$ : フリ一側堅ロール上圧延荷重補正係数

$\mathrm{Q}_{\mathrm{VFL}}$ ：フリ一側竪ロール下压延荷重補正係数

$\mathrm{P}_{\mathrm{E}}$ : エッジャ圧延荷重

$\mathrm{k}_{\mathrm{m}}$ ：平均変形抵抗

$\mathrm{K}_{\mathrm{H}}$ ：ユニバーサル水平ロールミル剛性

$\mathrm{K}_{\mathrm{VD}}$ ：ユニバーサルドライブ側竪ロールミル岡性

$\mathrm{K}_{\mathrm{VF}}$ : ユニバーサルフリー側堅ロールミル剛性

$\mathrm{K}_{\mathrm{E}}$ : エッジャミル岡性

(添字)

1 : エッジャ圧延前

E : エ エッジャ圧延後

2 : ユニバーサル圧延後(前)

\section{文献}

1) 平沢猛志，中内一郎，甫之瀬弘之：鉄と鋼，66(1980)，p.15

2 ) 平沢猛志：形鋼庄延技術の最近の進步, 鉄鋼協会l延理論部会 30周年記念シンポジウム, (1985), p.369

3 ) 浅田 司, 西修義夫, 森岡清孝, 中内一郎：鉄と鋼，67 (1981) p. 289

4 ) 鎌田正誠, 鈴木 弘：塑性と加工, 9(1968), p.395

5 ）鎌田正誠，鈴木 弘：塑性と加上，9(1968), p.459

6 ）浜田圭一，鈴木 弘：生産研究, 24(1972), p.126

7 ) 板圧延の理論 $と$ 実際 (日本鉄鋼協会編)，(1984), p.36

8 ）斎藤好弘：塑性と加工, 11(1970), p.736

9 ）特許, 压延ロールスラスト方向調整装置」半1-54121 